\title{
SYNTHESIS OF 1-BENZOYL-3-PHENYL-1H-PYRAZOLE-4-CARBALDEHYDE AND EVALUATION OF THEIR ANTIOXIDANT AND ANTI-INFLAMMATORY ACTIVITY
}

\author{
BONO NAGA SUDHA*, N YELLA SUBBAIAH, MANCHALA MAHALAKSHMI
}

Department of Pharmaceutical Chemistry, CES College of pharmacy, Kurnool-518218, Andhra Pradesh, India. Email: drbnsudha@gmail.com

Received: 11 April 2021, Revised and Accepted: 28 August 2021

\section{ABSTRACT}

Objective: The main objective of this study is to synthesize a series of 1-Benzoyl-3-phenyl-1H-pyrazole-4-carbaldehyde (4a-e) derivatives and evaluation of the synthesized compounds for their antioxidant and anti-inflammatory activity.

Methods: A series of substituted acetophenones are condensed with hydrazides to the corresponding hydrazones which are subsequently cyclized by using vilsmier-Haack reaction to give final series of 1-Benzoyl-3-phenyl-1H-pyrazole-4-carbaldehyde (4a-e) derivatives respectively. All newly synthesized compounds were characterized on the basis of infrared, proton nuclear magnetic resonance and mass spectral data and screened for their antioxidant and anti-inflammatory activities.

Results: In view of the significant biological activity profile of Pyrazole, the synthesized compounds (4a-e) were evaluated for their antioxidant potency by DPPH, Nitric oxide, Hydroxyl radical scavenging, and Hydrogen Peroxide method. Compounds 4c and 4e showed potent antioxidant activity then standard. Synthesized compounds were also screened for anti-inflammatory activity. Among all the molecules $4 \mathrm{c}$, $4 \mathrm{e}$, and $4 \mathrm{~d}$ showed significant activity as compared to standard drug diclofenac sodium.

Conclusion: in this study, we synthesized 1-Benzoyl-3-phenyl-1H-pyrazole-4-carbaldehyde (4a-e) derivatives. Further, these derivatives showed significant antioxidant and anti-inflammatory activity. Among them, two molecules $4 \mathrm{c}$ and $4 \mathrm{e}$ have shown near action to the standard.

Keywords: Pyrazoles, Hydrazones, Vilsmier-Haack reaction, Antioxidant and anti-inflammatory activity.

(C) 2021 The Authors. Published by Innovare Academic Sciences Pvt Ltd. This is an open access article under the CC BY license (http://creativecommons.org/ licenses/by/4.0/) DOI: http://dx.doi.org/10.22159/ajpcr.2021v14i10.41779. Journal homepage: https://innovareacademics.in/journals/index.php/ajpcr

\section{INTRODUCTION}

Pyrazoles are unique in their chemical behavior not only among heterocyclic compounds in general but also among related azoles. Pyrazoles are also a class of compounds that have the ring C3N2. The drugs containing a pyrazole ring are celecoxib and stanozolol.

The possibility that pyrazole is used directly in the synthesis of the amino acid has been investigated by supplying young melon seedlings with pyrazole alone and in association with various amino acids. The term pyrazole was given to this class of compounds by German Chemist Ludwig Knorr in 1883. In a classical method developed by German chemist Hans von Pechmann in 1898, pyrazole was synthesized from acetylene and diazomethane. In 1959, the first natural pyrazole, 1-pyrazolyl-alanine, was isolated from seeds of watermelons [1]. During the past years, considerable evidences have also accumulated to demonstrate the efficacy of pyrazoles including antimicrobial $[2,3]$, anti-Inflammatory [4], anticonvulsant [5], antitubercular [6,7] antiproliferative, antiangiogenic [8], hypoglycemic agent, antimalarial agent, anti-viral, and analgesic activity [9].

In view of above mentioned pharmacological importance of pyrazoles, we aimed to synthesize series of substituted pyrazole analogs by the Vilsmeier-Haack reaction method, in order to investigate the effect of pyrazole on their in vitro antioxidant and anti-inflammatory activity.

\section{MATERIALS AND METHODS}

All chemicals used were of Laboratory Reagents grade. Entire chemicals required for the synthesis and other experimental work were obtained from SD fine chemicals India and Molychem. Melting points of all synthesized compounds were determined in open capillaries on tempo apparatus. Spectroscopic data were recorded by the following instruments: Proton nuclear magnetic resonance ( ${ }^{1} \mathrm{H}$ NMR) spectra were recorded by BRUKER- $300 \mathrm{MHz}$; MASS spectra were recorded in apex mass spectrometer. Infrared (IR) spectra were recorded on BRUKER alpha Fourier transform IR spectrometer. Purity of the samples was checked by thin-layer chromatography (TLC) using silica gel-G precoated plates and spots were detected by Ultraviolet chamber

\section{Chemistry}

The reaction sequences employed for the synthesis of title compounds are shown in Fig. 1. The first step was begun to convert 4-methoxybenzoic acid to 4 -methoxymethyl benzoate $\mathbf{1}$ by the standard esterification method [10]. 4-Methoxybenzoyl hydrazine 2 was synthesized in good yield from the reaction of ester $\mathbf{1}$ with excess of hydrazine hydrate in ethanol. Refluxing a mixture of acid hydrazide $\mathbf{2}$ and the substituted acetophenone in methanol afforded the corresponding $\mathrm{N}^{1}$-(1-phenyl ethylidene) benzohydrazide (3a-e) which were directly converted into the respective 1-Benzoyl-3-phenyl-1H-pyrazole-4-carbaldehyde (4a-4e) in good yield (Scheme) using V.H reagent (DMF/ $\mathrm{POCl}_{3}$ ). The structures of 1-Benzoyl-3-phenyl-1H-pyrazole-4-carbaldehyde (4a-4e) were confirmed by spectral and analytical data.

General procedure for the synthesis of methyl benzoate (1a-e) Substituted benzoic acid ( $0.01 \mathrm{~mol})$, in $25 \mathrm{ml}$ of methanol and $0.5 \mathrm{ml}$ of conc $\mathrm{H}_{2} \mathrm{SO}_{4}$ was added through sides of the walls. The resulting mixture was allow to reflux for $3 \mathrm{~h}$, the contents were allow to cool on water bath and were neutralized with $5 \% \mathrm{NaHCO}_{3}$ solution. The separated precipitate was the filtered and recrystallized from methanol.

General procedure for the synthesis of acidhydrazide (2a-e) A mixture of methyl benzoate (1a-b) $(0.01 \mathrm{~mol})$ and hydrazine hydride $(99 \%)(4 \mathrm{ml})$ in $20 \mathrm{ml}$ of methanol was heated under reflux for 4-5 h. 


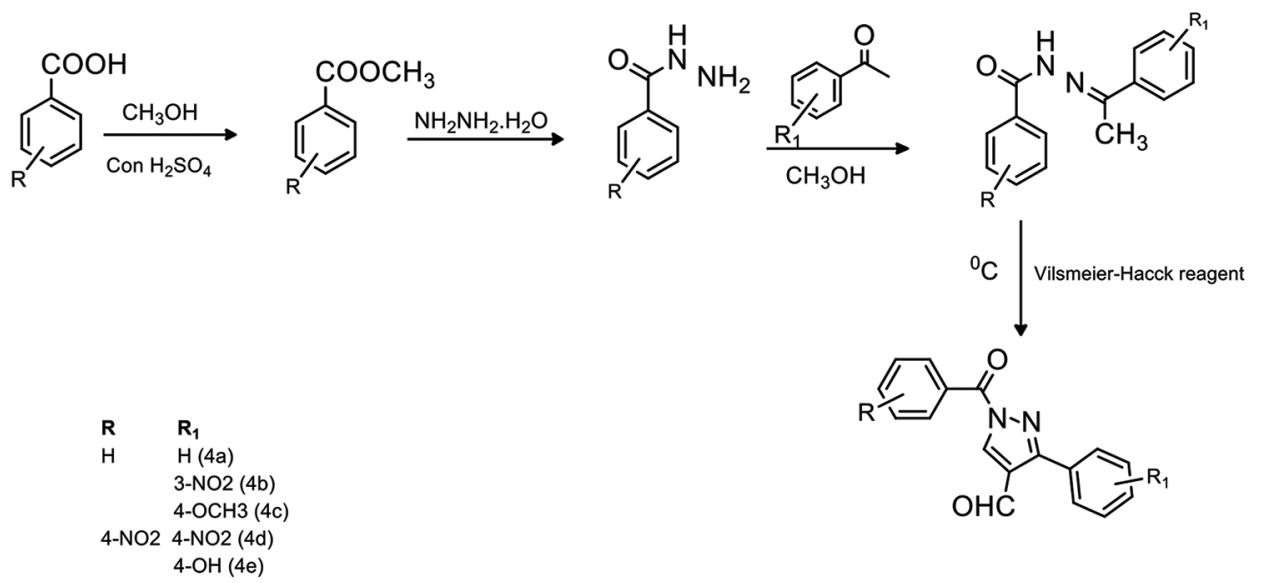

Fig. 1: Scheme: Conventional method for synthesis of 1-Benzoyl-3-phenyl-4-carbaldehyde

The reaction mixture was left overnight at room temperature and the solid separated was collected by filtration. It was washed thoroughly with water. The product was purified by recrystallization from methanol.

General procedure for the synthesis of $\mathrm{N}^{1}$-(1-phenyl ethylidene) benzohydrazide (3a-e)

Mixture of acid hydrazides (2a-e) $(0.01 \mathrm{~mol})$ and substituted acetophenone $(0.01 \mathrm{~mol})$ in methanol $(30 \mathrm{ml})$ and 3-4 drops of glacial acetic acid was heated under refluxed for $2 \mathrm{~h}$. The reaction mixture was cool to room temperature. The separated precipitate was the filtered and washes thoroughly with water, dried, and recrystallized with methanol.

General procedure for the synthesis of 1-Benzoyl-3-phenyl-1Hpyrazole-4-carbaldehyde w(4a-e)

$\mathrm{N}^{1}$-(1-phenyl ethylidene) benzohydrazide (3a-e) (0.004 mol) and mixture of Vilsmeier-Hacck reagent (prepared from $10 \mathrm{ml}$ of DMF and $1.1 \mathrm{ml}\left[0.012 \mathrm{~mole} \mathrm{POCl}_{3} \mathrm{at}^{\circ} \mathrm{C}\right.$ ) was added in small aliquots at a time and the reaction mixture was stirred at $60-65^{\circ} \mathrm{C}$ for $4 \mathrm{~h}$. Completion of the reaction was judged by TLC. The reaction mixture was slowly quenched into crushed ice with stirring and neutralized it with solid $\mathrm{NaHCO}_{3}$. The precipitate was filtered off, dried, and purified by recrystallization from methanol.

\section{4a: 1-Benzoyl-3-phenyl-1H-Pyrazole-4-carbaldehyde}

IR (KBr) $\left(\mathrm{cm}^{-1}\right): 1628$ (C=O str), 1557.21 (C=N str), 779.1 (C-H ben), 2762.51 (C-H str, CHO), 1647.13 (C=O str, CHO), 2990.45 (Ar-C-H str); 1H NMR (DMSO), $\delta$ ppm: 9.1-9.32 $\delta(1 \mathrm{H}, \mathrm{s}, \mathrm{CHO}), 6.2-6.98 \delta(5 \mathrm{H}, \mathrm{m})$, $8.10 \delta(1 \mathrm{H}, \mathrm{s}), 7.02-7.87 \delta(5 \mathrm{H}, \mathrm{m})$; GC-MS $(\mathrm{m} / \mathrm{z}, \%): 278(\mathrm{M}+2)$; Anal. Calcd for $\mathrm{C}_{17} \mathrm{H}_{12} \mathrm{~N}_{2} \mathrm{O}_{2}: \mathrm{C}, 73.90 ; \mathrm{H}, 4.38 ; \mathrm{N}, 10.14 ; 0,11.58$. Found: $\mathrm{C}$, 74.02; H, 4.20; N, 10.14; 0, 11.24.

4b: 1-Benzoyl-3-(3-Nitrophenyl)-1H-pyrazole-4-carbaldehyde IR ( $\mathrm{KBr})\left(\mathrm{cm}^{-1}\right)$ : 1633 (C=0 str), 1529.42 ( $\mathrm{C}=\mathrm{N} \mathrm{str}$ ), 1348 (Ar-NO2 str), 712.8 (C-H ben), 3100.34 (Ar-C-H str) 2798.32 (C-H str, CHO), 1640 (C=O str, CHO); $1 \mathrm{H}$ NMR (DMSO), $\delta \mathrm{ppm:} \mathrm{9.17-9.24} \delta(1 \mathrm{H}, \mathrm{s}, \mathrm{CHO})$, 5.98-6.59 $\delta(5 \mathrm{H}, \mathrm{m}), 8.24 \delta(1 \mathrm{H}, \mathrm{s}), 6.98-7.94 \delta(4 \mathrm{H}, \mathrm{m})$; Anal. Calcd for $\mathrm{C}_{17} \mathrm{H}_{11} \mathrm{~N}_{3} \mathrm{O}_{4}: \mathrm{C}, 63.55 ; \mathrm{H}, 3.45 ; \mathrm{N}, 13.08 ; 0,19.92$. Found: $\mathrm{C}, 63.84 ; \mathrm{H}, 3.49$; $\mathrm{N}, 13.09 ; 0,19.86$

4c: 1-Benzoyl-3-(4-methoxyphenyl)-1H-pyrazole-4-carbaldehyde IR (KBr) $\left(\mathrm{cm}^{-1}\right)$ : 1603 ( $\left.\mathrm{C}=0 \mathrm{str}\right), 1529.10$ ( $\mathrm{C}=\mathrm{N}$ str), 712.8 (C-H ben), 3100.34 (Ar-C-H str) 2792 (C-H str, CHO), 1629.76 (C=O str, CHO) 2816.04 (C-H str, OCH3); $1 \mathrm{H}$ NMR (DMSO), $\delta$ ppm: $9.7 \delta(1 \mathrm{H}, \mathrm{s}, \mathrm{CHO})$, 6.14-6.53 $\delta(5 \mathrm{H}, \mathrm{m}), 7.95 \delta(1 \mathrm{H}, \mathrm{s}), 3.65(3 \mathrm{H}, \mathrm{s}, \mathrm{OCH} 3), 7.01-7.72 \delta$ $(4 \mathrm{H}, \mathrm{m})$; GC-MS (m/z,\%): $306(\mathrm{M}+)$; Anal. Calcd for $\mathrm{C}_{18} \mathrm{H}_{14} \mathrm{~N}_{2} \mathrm{O}_{3}$ : C, 70.58; H, 4.61; N, 9.15; O, 15.67. Found: C, 70.64; H, 4.57; N, 9.09; O, 15.62 . 4d: 1-(4-Nitrobenzoyl)-3-phenyl-1H-pyarazole-4-carbaldehyde IR (KBr) $\left(\mathrm{cm}^{-1}\right.$ ): 1609.53 (C=0 str), 1542 (C=N str), 709.2 (C-H ben), 3024.64 (Ar-C-H str) 2817.47 (C-H str, CHO), 1659.38 (C=0 str, CHO), 1354.96 (Ar-NO2 str); $1 \mathrm{H}$ NMR (DMSO), $\delta$ ppm: $9.3 \delta(1 \mathrm{H}, \mathrm{s}, \mathrm{CHO})$, 7.2- $7.82 \delta(5 \mathrm{H}, \mathrm{m}), 8.2 \delta(1 \mathrm{H}, \mathrm{s}), 7.86-8.85 \delta(4 \mathrm{H}, \mathrm{m})$; GC-MS $(\mathrm{m} / \mathrm{z}, \%)$ : $322(\mathrm{M}+1)$; Anal. Calcd for $\mathrm{C}_{17} \mathrm{H}_{11} \mathrm{~N}_{3} \mathrm{O}_{4}: \mathrm{C}, 63.55 ; \mathrm{H}, 3.45 ; \mathrm{N}, 13.08 ; \mathrm{O}$, 19.92. Found: C, $63.13 ; \mathrm{H}, 3.25 ; \mathrm{N}, 13.49 ; \mathrm{O}, 19.12$.

\section{4e:3-(4-Hydroxyphenyl)-1-(4-nitrobenzoyl)-1H-Pyrazole-4- carbaldehyde}

IR (KBr) $\left(\mathrm{cm}^{-1}\right)$ : 1604.05 (C=0 str), 1586 (C=N str), 722.2 (C-H ben), 3045 (Ar-C-H str) 2854.22 (C-H str, CHO), 1670 (C=O str, CHO), 1350.32 (Ar-NO2 str), 3230.34 (Ar-OH str); 1H NMR (DMSO), $\delta$ ppm: $9.5 \delta$ $(1 \mathrm{H}, \mathrm{s}, \mathrm{CHO}), 6.7-7.02 \delta(4 \mathrm{H}, \mathrm{m}), 8.27 \delta(1 \mathrm{H}, \mathrm{s}), 7.89-8.4 \delta(4 \mathrm{H}, \mathrm{m}) 5.92 \delta$ $(1 \mathrm{H}, \mathrm{s}, \mathrm{Ar}-\mathrm{OH})$; Anal. Calcd for $\mathrm{C}_{17} \mathrm{H}_{11} \mathrm{~N}_{3} \mathrm{O}_{5}: \mathrm{C}, 60.54 ; \mathrm{H}, 3.29 ; \mathrm{N}, 12.46$; $\mathrm{O}$, 23.72. Found: C, 60.10; H, 3.12; N, 12.28; O, 23.71.

\section{In vitro antioxidant activity}

2,2-Diphenylpicrylhydrazyl (DPPH) free radical - scavenging activity

The DPPH free radical scavenging capability was performed as the method described by Altarejos et al. [11]. Methanolic solution of DPPH $(1.0 \mathrm{~mL}, 0.1 \mathrm{mM})$ was mixed with $3.0 \mathrm{~mL}$ of sample solution of different concentrations ranging from 10 to $320 \mu \mathrm{g} / \mathrm{ml}$. The reaction mixture was incubated in dark at room temperature for $30 \mathrm{~min}$ and the absorbance was recorded at $517 \mathrm{~nm}$ against a blank. The assay was carried out in triplicate for each sample. The radical scavenging activity of ascorbic acid was also determined as standard. IC $_{50}$ values (concentration required to scavenge $50 \%$ of free radicals) of both ascorbic acid and test samples were determined. The activity was expressed by the inhibition percentage (I \%) of DPPH radical, following the equation (1).

$\mathrm{I} \%=[(\mathrm{Ac}-\mathrm{As}) / \mathrm{Ac}] \times 100$

Where, Ac and As are the absorbance of the control and of the test/ standard sample respectively.

Nitric oxide scavenging activity

Nitric oxide radical scavenging activity was determined according to the method reported by Marcocci et al. [12]. In this assay, sample solution $(4 \mathrm{ml})$ at different concentration $(10-320 \mu \mathrm{g} / \mathrm{ml})$ was mixed with $1.0 \mathrm{~mL}$ of $25 \mathrm{mM}$ sodium nitroprusside solution in a test tube, and incubated for $2 \mathrm{~h}$ at $37^{\circ} \mathrm{C}$. Incubated solution $(2 \mathrm{~mL})$ was mixed with $1.2 \mathrm{~mL}$ Griess reagent (1\% sulfanilamide in $5 \% \mathrm{H}_{3} \mathrm{PO}_{4}$ and $0.1 \%$ naphthyl ethylenediamine dihydrochloride). which results in diazotization of the nitrite with sulfanilamide and subsequent coupling with naphthyl ethylenediamine dihydrochloride to form a chromophore. The absorbance of chromophore was measured immediately at $570 \mathrm{~nm}$. Control experiment was also carried out in similar manner taking same 
volume of distilled water in the place of sample solution. The experiment was performed in triplicate, ascorbic acid was used as positive control and percentage scavenging activity was calculated using the equation (1).

\section{Hydroxyl radical scavenging activity}

The hydroxyl radical scavenging activity of sample was assayed by using the 2-deoxyribose oxidation method Sakanaka et al. [13]. To the reaction mixture containing $0.2 \mathrm{ml} \mathrm{KH}_{2} \mathrm{PO}_{4}-\mathrm{KOH}(100 \mathrm{mM}), 0.2 \mathrm{ml}$ deoxyribose (15 mM), $0.2 \mathrm{ml} \mathrm{FeCl}$ (500 mM), $0.1 \mathrm{ml}$ EDTA $(1 \mathrm{mM})$, $0.1 \mathrm{ml}$ ascorbic acid $(1 \mathrm{mM})$, and $0.1 \mathrm{ml} \mathrm{H}_{2} \mathrm{O}_{2}(10 \mathrm{mM})$ were mixed with $0.1 \mathrm{ml}$ sample. The mixture was incubated at $37^{\circ} \mathrm{C}$ for $1 \mathrm{~h}$. After incubation time, $1.0 \mathrm{ml}$ of TBA $(1 \% \mathrm{w} / \mathrm{v})$ was added to mixture followed by the addition of $1.0 \mathrm{ml}$ of TCA $(2.8 \% \mathrm{w} / \mathrm{v})$. The resultant mixture was heated on a water bath at $80^{\circ} \mathrm{C}$ for $20 \mathrm{~min}$, so that pink color developed. The absorbance of the solution was measured at $532 \mathrm{~nm}$. Ascorbic acid was used as the positive control. The scavenging activity of test sample or standard (I \%) was calculated using the equation (1).

\section{Hydrogen peroxide scavenging activity}

This assay was carried out according to the method of Bozin et al. [14]. A solution of $40 \mathrm{mM} \mathrm{H}_{2} \mathrm{O}_{2}$ and test samples/standard in different concentrations were prepared in phosphate buffer ( $\mathrm{pH} 7.4$ ). $3.4 \mathrm{ml}$ of sample solution was added to $0.6 \mathrm{~mL}$ of $\mathrm{H}_{2} \mathrm{O}_{2}$ solution and the absorbance of resulting solutions was measured at $230 \mathrm{~nm}$. Ascorbic acid was used as standard. The percentage of $\mathrm{H}_{2} \mathrm{O}_{2}$ scavenging (I \%) of tested sample was calculated by equation (1).

\section{Anti-inflammatory activity}

Acute toxicity studies

The acute toxicity study was determined in rats. Rats fasted for $12 \mathrm{~h}$ were randomly divided into different groups of 3 rats per group. All the animals were then allowed free access to food and water and observed over a period of $48 \mathrm{~h}$ for signs of acute toxicity. The number of deaths within this period was recorded. Based on the results of the preliminary toxicity test, the doses of $50 \mathrm{mg} / \mathrm{kg}, 100 \mathrm{mg} / \mathrm{kg}$ body weight (according to OECD Guideline 423) of were chosen for further experiments.

\section{Animals}

Albino (Wistar Strain) rats (150-250 g) were used in the study of anti-inflammatory activity and international principle and local regulations concerning the care and use of laboratory animals were taken into account [15]. Animal ethics committee approval was obtained from the institutional ethical committee (Registration number: 1305/ ac/09/ CPCSEA). The animals were maintained under environmental condition and had free access to standard diet and freshwater ad libitum. They were housed in animal cages at room temperature $\left(30 \pm 2^{\circ} \mathrm{C}\right)$ and $60-65 \%$ relative humidity.

Anti-inflammatory activity (carrageenan-induced rat hind paw edema model) The anti-inflammatory activity of test compounds was carried out by carrageenan-induced rat hind paw edema method by Winter et al. [16].
Carboxy methylcellulose $(0.5 \% \mathrm{w} / \mathrm{v}$ solution) was selected as vehicle to suspend the standard drugs and the test compounds. The albino rats weighing between 150 and $200 \mathrm{~g}$ were starved for $18 \mathrm{~h}$ prior to the experiment. The animals were weighed, marked for identification, and divided into 12 groups each group containing 6 animals. Edema was induced in the left hind paw of all rats by subcutaneously to the sub plantar injection of $0.1 \mathrm{ml}$ of $1 \%$ carrageenan in normal saline into their footpads. The first group served as control received $0.5 \mathrm{ml}$ of carboxymethyl chitosan (CMC) $(0.5 \% \mathrm{w} / \mathrm{v}$ solution). The second group (standard) was treated with diclofenac sodium at a dose of $10 \mathrm{mg} / \mathrm{kg}$ and test compounds were administered p.o. as suspension in $0.5 \%$ $\mathrm{CMC}, 1 \mathrm{~h}$ prior the injection of the test compounds at dose levels of $50 \mathrm{mg} / \mathrm{kg}$ and $100 \mathrm{mg} / \mathrm{kg}$ as suspension in $0.5 \%$ CMC. The paw volume was measure immediately $(0 \mathrm{~h})$ and after 30-180 min, respectively, using digital plethysmometer. Percentage inhibition in the paw edema was calculated according to the following equation (2).

$$
\% \text { Inhibition }=\{1-(\mathrm{A}-\mathrm{X} / \mathrm{B}-\mathrm{Y})\} \times 100
$$

Where, $\mathrm{A}$ is the mean paw volume after administration of drug $(\mathrm{ml})$, $\mathrm{X}$ is the mean paw volume before administration of drug $(\mathrm{ml}), \mathrm{B}$ is the mean paw volume of treated control rats, $\mathrm{Y}$ is the mean paw volume of treated control rats before administration of carrageenan. Percentage inhibition shown by tested compounds is recorded in Table 1 and Fig. 2.

\section{RESULTS AND DISCUSSION}

In the present work, five derivatives of pyrazoles were synthesized. The structures of synthesized compounds were established by their spectral data. According to IR spectroscopic data compounds (4a- 4e) showed absorption bands at 2987, 2790, 1756, 1640, 1605, and $1340 \mathrm{~cm}^{-1}$ indicating the presence of $\mathrm{Ar} \mathrm{C}-\mathrm{H}, \mathrm{C}=\mathrm{O}$, aldehyde $\mathrm{C}-\mathrm{H}, \mathrm{C}=\mathrm{O}$, and pyrazole $\mathrm{C}=\mathrm{N}, \mathrm{C}-\mathrm{N}$ groups, respectively. $1 \mathrm{H}$ NMR spectra of the synthesized compounds were confirmed by the appearance of - $\mathrm{CHO}$ proton at $\delta 9.4$ and $\mathrm{CH}$ proton of pyrazole ring at $\delta 8.2$ as singlet. Peaks due to two phenyl groups appeared at $\delta 7.2-7.8$ as multiplet. Further, LC mass spectrum showed molecular ion peak at m/z $306(100 \%)$ in agreement with their molecular formula.

The synthesized compounds were screened for their in vitro antioxidant activity by DPPH, hydrogen peroxide, Nitric Oxide, and hydroxyl radical scavenging method and the results are reported in Figs. 3-6, respectively. The data reveal that synthesized compounds showed moderate to good inhibition activity compared to the standard. Out of all the synthesized compounds, $4 \mathrm{e}(4-\mathrm{OH})$ and $4 \mathrm{c}(\mathrm{H})$ derivatives showed good antioxidant activity in all the four methods. The synthesized compounds were subjected to anti-inflammatory activity by the carrageenan-induced rat hind paw edema method at the low and high dose of $50 \mathrm{mg} / \mathrm{kg}$ and $100 \mathrm{mg} / \mathrm{kg}$ and the results are summarized in Table 1 and Fig. 2, respectively. The entire compounds have a good response for anti-inflammatory activity. Among all these 4-hydroxy and unsubstituted derivatives showed good reduction of edema at high dose (100 mg/ kg). Similarly, compound 4d (4-methoxy) showed

Table 1: Anti-inflammatory potential of test compounds (4a-e) on carrageenan-induced rat paw edema method

\begin{tabular}{|c|c|c|c|c|c|c|c|c|}
\hline Tested compounds & $0 \mathrm{~min}$ & $30 \mathrm{~min}$ & $60 \mathrm{~min}$ & $90 \mathrm{~min}$ & $120 \mathrm{~min}$ & $150 \mathrm{~min}$ & $180 \mathrm{~min}$ & $\%$ Protection \\
\hline Control & $0.25 \pm 0.09$ & $0.30 \pm 0.07$ & $0.37 \pm 0.08$ & $0.45 \pm 0.06$ & $0.45 \pm 0.05$ & $0.46 \pm 0.05$ & $0.46 \pm 0.05$ & \\
\hline Standard & $0.27 \pm 0.08$ & $0.37 \pm 0.03$ & $0.40 \pm 0.07$ & $0.48 \pm 0.05$ & $0.38 \pm 0.07$ & $0.44 \pm 0.04$ & $0.30 \pm 0.02$ & 85.71 \\
\hline $4 \mathrm{a}(50 \mathrm{mg})$ & $0.26 \pm 0.07$ & $0.35 \pm 0.04$ & $0.39 \pm 0.05$ & $0.44 \pm 0.06$ & $0.45 \pm 0.05$ & $0.44 \pm 0.04$ & $0.42 \pm 0.04$ & 23.8 \\
\hline $4 a(100 \mathrm{mg})$ & $0.25 \pm 0.03$ & $0.35 \pm 0.03$ & $0.37 \pm 0.06$ & $0.41 \pm 0.07$ & $0.43 \pm 0.03$ & $0.42 \pm 0.03$ & $0.39 \pm 0.03$ & 33.33 \\
\hline $4 \mathrm{~b}(50 \mathrm{mg})$ & $0.29 \pm 0.06$ & $0.39 \pm 0.06$ & $0.44 \pm 0.07$ & $0.47 \pm 0.04$ & $0.48 \pm 0.07$ & $0.45 \pm 0.05$ & $0.41 \pm 0.05$ & 42.85 \\
\hline $4 \mathrm{~b}(100 \mathrm{mg})$ & $0.24 \pm 0.03$ & $0.35 \pm 0.06$ & $0.38 \pm 0.05$ & $0.41 \pm 0.04$ & $0.39 \pm 0.07$ & $0.38 \pm 0.02$ & $0.34 \pm 0.06^{*}$ & 52.38 \\
\hline $4 c(50 \mathrm{mg})$ & $0.26 \pm 0.05$ & $0.32 \pm 0.04$ & $0.42 \pm 0.04$ & $0.49 \pm 0.07$ & $0.45 \pm 0.06$ & $0.40 \pm 0.04$ & $0.38 \pm 0.03$ & 42.85 \\
\hline $4 d(50 \mathrm{mg})$ & $0.28 \pm 0.05$ & $0.34 \pm 0.07$ & $0.39 \pm 0.05$ & $0.44 \pm 0.06$ & $0.41 \pm 0.05$ & $0.40 \pm 0.04$ & $0.38 \pm 0.04$ & 52.38 \\
\hline $4 d(100 \mathrm{mg})$ & $0.24 \pm 0.05$ & $0.32 \pm 0.05$ & $0.37 \pm 0.06$ & $0.43 \pm 0.05$ & $0.39 \pm 0.06$ & $0.34 \pm 0.03$ & $0.31 \pm 0.06^{* *}$ & 66.66 \\
\hline $4 \mathrm{e}(50 \mathrm{mg})$ & $0.26 \pm 0.04$ & $0.36 \pm 0.06$ & $0.45 \pm 0.04$ & $0.47 \pm 0.05$ & $0.43 \pm 0.05$ & $0.41 \pm 0.04$ & $0.40 \pm 0.02$ & 33.33 \\
\hline $4 \mathrm{e}(100 \mathrm{mg})$ & $0.30 \pm 0.04$ & $0.38 \pm 0.07$ & $0.40 \pm 0.03$ & $0.42 \pm 0.04$ & $0.38 \pm 0.07$ & $0.37 \pm 0.05$ & $0.36 \pm 0.05^{*}$ & 71.42 \\
\hline
\end{tabular}

Results are expressed as a mean \pm SEM significant at $* \mathrm{p}<0.05{ }^{* *} \mathrm{p}<0.01{ }^{* * *} \mathrm{p}<0.001$, is calculated by comparing with standard by one way ANOVA 


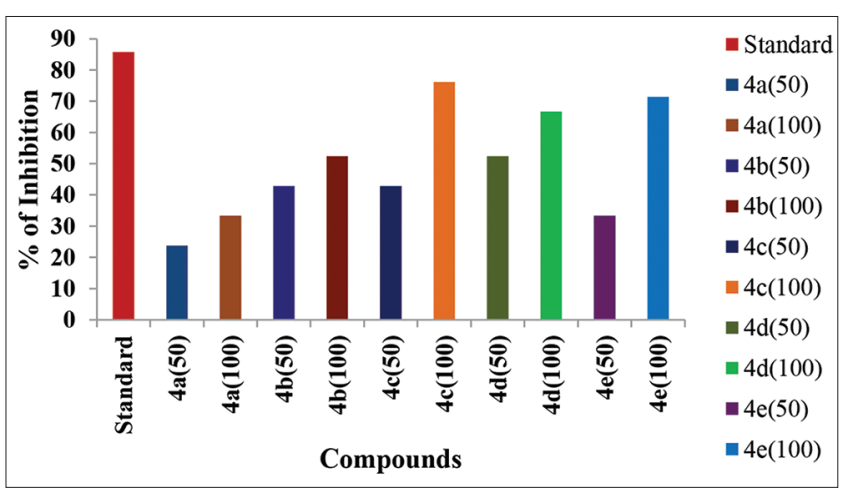

Fig. 2: Anti-inflammatory potential of test compounds (4a-e) on carrageenan-induced rat paw edema

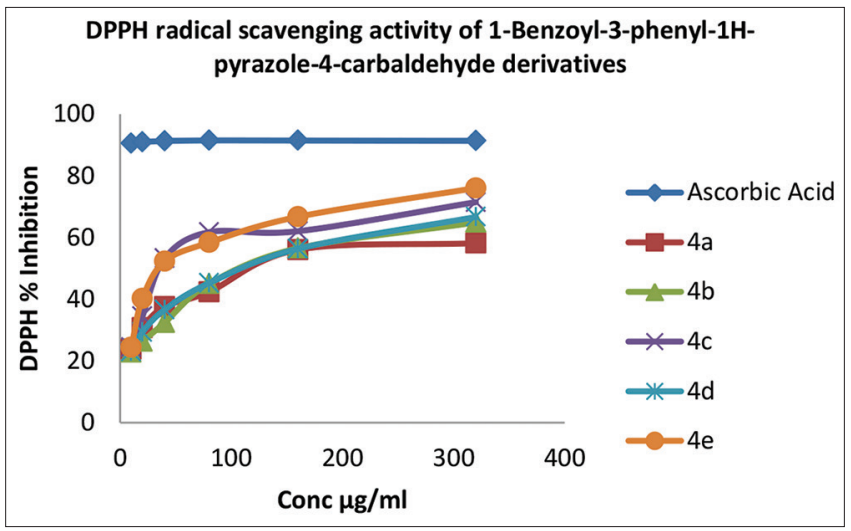

Fig. 3: DPPH radical scavenging method

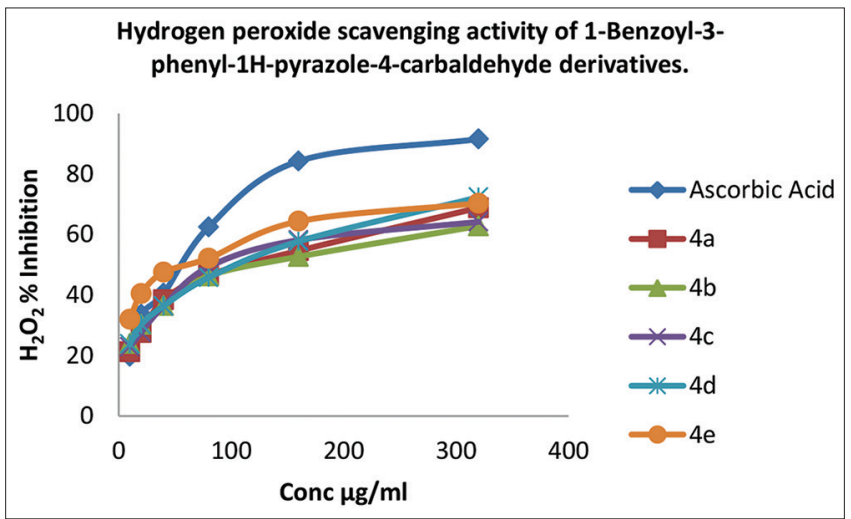

Fig. 4: Hydrogen peroxide scavenging method

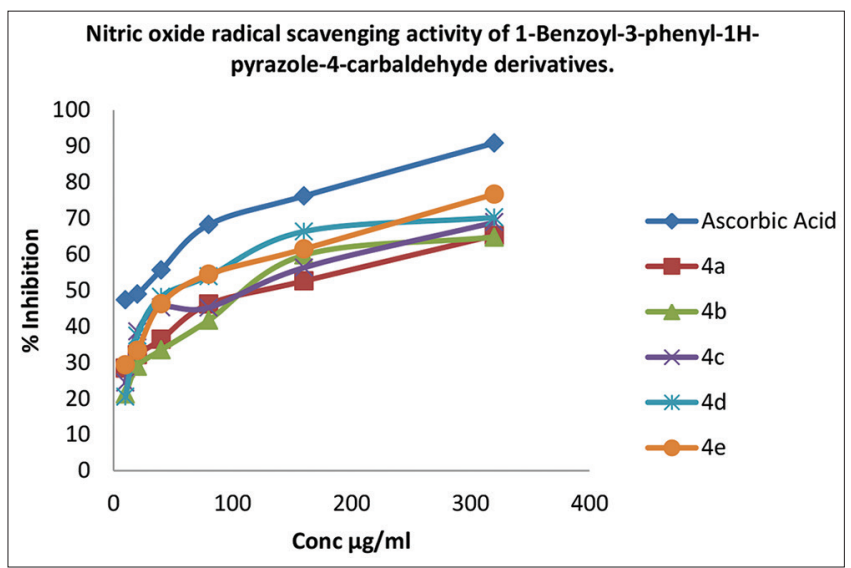

Fig. 5: Nitric oxide radical scavenging method

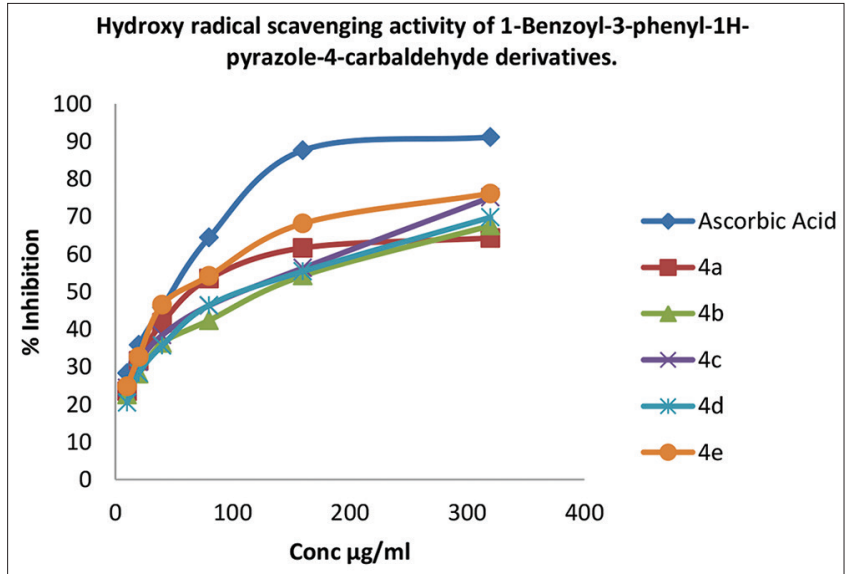

Fig. 6: Hydroxy radical scavenging method

good protection effect at low dose $(50 \mathrm{mg} / \mathrm{kg})$. Compounds $4 \mathrm{a}, 4 \mathrm{~b}$, and $4 \mathrm{c}$ have relatively moderate anti-inflammatory activity. It was further concluded that presence of electron-donating groups at para position of phenyl nucleus showed maximum antioxidant and anti-inflammatory activity.

\section{CONCLUSION}

In this work, a series of 1-Benzoyl-3-phenyl-1H-pyrazole-4carbaldehyde derivatives is prepared. The synthesized compounds were purified and well-characterized by TLC, IR, ${ }^{1} \mathrm{HNMR}$, and GC-MS data. The antioxidant and anti-inflammatory data revealed that the compound with electron-donating group at para position on the ring exhibit significant action it makes the ring with prompt aromatic to exhibit action and therefore might serve as a lead molecule to obtain more clinically useful, novel entities in the future.

\section{ACKNOWLEDGEMENT}

We are thankful to Creative Educational Society's College of Pharmacy, Kurnool, Andhra Pradesh, India, for providing laboratory facilities. It's my privilege to express my sincere thanks to SAIF IIT, Madras for the spectral analysis of compounds.

\section{CONFLICTS OF INTEREST}

Authors declare that they have no conflicts of interest.

\section{AUTHORS' CONTRIBUTIONS}

All the authors have contributed equally.

\section{AUTHORS FUNDING}

The authors did not receive any funding for the research work

\section{REFERENCES}

1. Noe FF, Fowden A. Heterocyclic amino acid, B-pyrazol-lylalanine, was isolated from the seeds of watermelon (Citrullus vulgaris) and its structure confirmed by comparison with synthetic material. Biochem J 1960;77:543-6.

2. Abdel Aziz SA, El-Sayed Ali T, El-Mahdy KM, Abde-Karim SM. Synthesis and antimicrobial activities of some novel bis-pyrazole derivatives containing a hydrophosphoryl unit. Eur J Chem 2011;2:25- 35 .

3. Shridhar M, Isloor MA, Akhila DS, Hoong-Kun F. Synthesis, characterization and antibacterial activity of some new pyrazole schiff bases. Arab J Chem 2013;6:335-40

4. Yassin FA. Novel pyrazolyl pyridazine derivatives likely to possess anti-inflammatory activity. J Microb Antimicrob 2010;2:93-99.

5. Abdel Aziz M, Rahma Gel DA, Hassan AA. Synthesis of novel pyrazole derivatives and evaluation of their antidepressant and anticonvulsant activities. Eur J Chem 2009;44:3480-4. 
6. Unnat P, Amit D. Synthesis and antitubercular activity of novel pyrazolequinazolinone hybrid analogs. Med Chem Res 2013;22:3364- 71

7. Pathak RB, Chovatia PT, Parekh HH. Synthesis, antitubercular and antimicrobial evaluation of 3-(4-chlorophenyl) 4-substituted pyrazole derivatives. Bioorg Med Chem Lett 2012;22:5129-33.

8. Tzanetou E, Liekens S, Kasiotis KM, Fokialakis N, Haroutounian SA. Novel pyrazole and indazole derivatives, synthesis and evaluation of their anti-proliferative and anti-angiogenic activities. Arch Pharm 2012;345:804-11.

9. Anadarajagopal K, Sunilson JA, Illavarasu A, Thangavelpandian N, Kalirajan R. Antiepileptic and antimicrobial activities of novel 1-(unsubstituted/substituted)-3,5-dimethyl-1h-pyrazole derivatives. Int J ChemTech Res 2010;2:45-9.

10. Brian ST, Antony JH, Peter WG, Austin RR. Vogel's: Practical Organic Chemistry. $5^{\text {th }}$ ed. New York: Longman Scientific Technical; 1989. p. 1077.

11. Altarejos J, Salido S, Bonilla MP, Palomino PJ, Beek TA, Nogueras M.
Preliminary assay on the free radical scavenging activity of olive wood extracts. Fitoterapia 2005;76:348-51.

12. Marcocci L, Maguire JJ, Droy-Lefaiz MT, Packer L. The nitric oxidescavenging properties of Ginkgo biloba eztract EGB 761. Biochem Biophys Res Commun 1994;201:748-55.

13. Sakanaka S, Tachibana Y, Okada Y. Preparation and antioxidant properties of extracts of Japanese persimmon leaf tea (kakinoha-cha). Food Chem 2005;89:569-75.

14. Bozin B, Mimica-Duki N, Samojlik I, Goran A, Igic R. Phenolics as antioxidants in garlic (Allium sativum Linn. Alliaceae). Food Chem 2008;111:925-9.

15. Olfert ED, Cross BM, McWilliam AA Guide to the Care and Use of Experimental Animals. $2^{\text {nd }}$ ed., Vol. 1. Ottawa, Ontario: Canadian Council on Animal Care; 1993.

16. Winter CA, Risley EA, Nuss GW. Carrageenin-induced edema in hind paw of the rat as an assay for anti-inflammatory drugs. Exp Biol Med 1962;111:544-7. 